\title{
Development of Online Science Teaching Instrument Based on Scientific Approach Using PhET Simulation to Improve Learning Outcomes at Elementary School
}

\author{
Taufik Adi Sarwoto', Budi Jatmiko ${ }^{2}$, Elok Sudibyo ${ }^{3}$ \\ 1,2,3 Univerisitas Negeri Surabaya, Surabaya, Indonesia
}

\begin{tabular}{|c|c|}
\hline 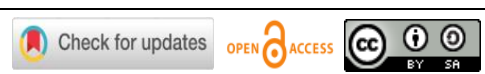 & DOI : https://doi.org/10.46245/ijorer.v1i2.40 \\
\hline Article Info & ABSTRACT \\
\hline $\begin{array}{l}\text { Article history: } \\
\text { Submitted: June 16, } 2020 \\
\text { Final Revised: July 13, } 2020 \\
\text { Accepted: July 14, 2020 } \\
\text { Published Online: July 31, } 2020\end{array}$ & \multirow{3}{*}{$\begin{array}{l}\text { The research aims to develop online science teaching instruments based on a } \\
\text { scientific approach using a proper PhET simulation to improve learning } \\
\text { outcomes for elementary school students. The developed equipment is the } \\
\text { lesson plan, students' activity sheet, learning materials, and assessment sheet } \\
\text { of learning outcomes. The research plan is designed in One Group Pre-Test- } \\
\text { Post-Test Design. The population in this study is all students of the fifth grade } \\
\text { of State Elementary School Jagir I academic year } 2019 / 2020 \text {. The results } \\
\text { showed that there is a significant improvement in the results of online science } \\
\text { studying through a scientific approach with the PhET simulation media. N- } \\
\text { Gain value of class A is of } 0.76 \text { and class B is } 0.70 \text { with high criteria. The } \\
\text { hypothesized test results showed no significant difference between class A } \\
\text { and class B, student learning outcomes in the psychomotor area values class A } \\
\text { in } 80 \text { when the average value of class B is } 77.08 \text {, the learning results in affective } \\
\text { domain values in class A is } 80.00 \text { in average and in class B is } 80.31 \text { with the } \\
100 \% \text { passing rate of the affective domain. }\end{array}$} \\
\hline $\begin{array}{l}\text { Keywords: } \\
\text { Developmental research } \\
\text { Learning outcomes } \\
\text { Online science teaching } \\
\text { PhET Simulation } \\
\text { Scientific approaches }\end{array}$ & \\
\hline & \\
\hline
\end{tabular}

\section{INTRODUCTION}

The competency-based curriculum is designed to provide students with a learning experience with the development of attitude, knowledge and skills competencies. Therefore, the school should be able to organize contextual learning according to government standards. The main element of the education process is the teachinglearning process to transfer knowledge to students through the learning process. Learning activities foster behavioral change called learning outcomes or learning achievements. Purwanto (2011) explains that learning outcomes are behavioral changes that occur after following the learning process according to educational objectives. Learning outcomes are abilities gained by individuals after the learning process, which can provide a change of behavior for knowledge, understanding, attitudes, and skills of the students to be better than before. Learning result is one of the indicators that shows the accomplishment or failure of the goal of a learning process.

The outcomes that achieved from the learning process should refer to the objectives of education established by the government. The learning objectives of science in elementary school is the understanding of science and skills to create a product that reflects the mastery of someone's competence as a result of the learning (Citrasmi et al., 2016). Therefore, improving the quality of education and teaching in Indonesia, especially in elementary school is essential to produce human resources, which are superior and quality in every era. One of the applications of the scientific approach in 2013 Curriculum is making the student to improve learning outcomes. In essence, K13 learning is learning by emphasizing authentic learning and assessment processes to achieve the competency of attitudes, knowledge, and skills. 
Learning uses a scientific approach designed to improve students' learning outcomes. The principles of the 5M scientific approach have been applied by the teacher to teach thematic science. However, the 5M principle indicators have not been fully implemented by the teacher in teaching thematic science as the teachers have no comprehensive understanding (Amir \& Haling, 2018). Learning with a scientific approach is learning that consists of observing activities (to identify things you want to know), formulating questions (and formulating hypotheses), trying/collecting data (information) with various techniques, associating/analyzing/processing data (information) and draw conclusions and communicate the results which consist of conclusions to obtain knowledge, skills, and attitudes. These steps can be continued by creating activities (Kemdikbud, 2014).

Learning with a scientific approach can support students to develop hands-on and minds-on (Duda, 2010) as well as their basic ability such as communication skills, interpersonal relations, critical thinking, and problem-solving skill (Lazanyi, 2012). Learning using a scientific approach can improve the ability of students both cooperatively and collaboratively. Therefore, exploration through learning activities by observation, making questions related to observation, conducting experiments, reasoning, and communicating results through various interpretations needs to be done continuously. To support science learning, students should not only learn facts, concepts, laws, and theories in science, but they should also learn the process of how products of science are created.

Based on the observation, State Elementary School Jagir I I do not have a science lab room so the practice cannot be done properly. The materials are given through conventional learning without carrying out the scientific performance (practice). This is because of the unavailability of equipment to directly implement the practice. Based on the test results of the material in the electrical circuit chapter, the average student values of 66 with the details of $42.25 \%$ complete and $57.75 \%$ uncompleted. Susilana \& Riyana (2017) explained that the learning outcomes of students as described by the cone of Edgar Dale's experience that knowledge would be more abstract if the message was only explained through verbal words. Learners only know about words without knowing and understanding the meaning contained therein, causing the low retention of knowledge. These facts show the electrical network material that has been studied has a low retention rate, so that when the repeat test was conducted, there were still many students that uncompleted the test. The students lack experience to discover their concepts. The learning is still less encouragement interaction, creativity, and motivation to learn students. Therefore, it is necessary to use learning resources or media to provide reinforcements to the material submitted. The application of interactive multimedia applications with a scientific approach can improve the quality of learning in elementary schools. The concrete thing that the teachers give will create better learning outcomes and the students will actively involve finding and build their knowledge.

In March 2020. the Indonesian government declared the closure of schools due to a Covid-19 outbreak so the learning process was diverted to online. This reinforces the researchers that it's time to study in an online class. It certainly requires the readiness of the students and teachers to achieve the objectives of the learning set. Educators should know the principles of learning and how students learn when using online learning. In designing an online learning material, there is not enough one theory to follow but rather to use a combination of theories. The learning approach should be known by 
material developers to choose the best learning strategy. Learning strategies should be well chosen to motivate students, to facilitate the learning process, to shape the whole person, to serve the individual differences, to elevate meaningful learning, to encourage interaction, to provide feedback, to facilitate contextual learning, and to encourage students during the learning process. Teachers play a crucial role to organize learning and coordinate all the components that affect students in the learning process to support the success of student achievement (Asrizal et al., 2018; Tuysuz, 2010).

Online learning views the students as the active learning center and the teachers are just facilitators. The students self-construct their knowledge, conjugate information, and interpret knowledge gained from the environment. Online learning allows students to define their learning objectives so that they learn something meaningful. The use of integrated science teaching materials that are equipped with digital literacy can give a meaningful impression (Asrizal et al., 2018). The online learning process can take any place as long as it is conductive and able to help to focus. Online learning uses a technology approach according to today's learning. The delivery method of an online class is a formal and informal mix. The students will get more engaged in teaching with a variety of media formats such as pictures, videos, or audio that will provide a more enjoyable learning experience and allow students to record and store provided material in digital form. That makes the students easily accessed and re-learned at a later. Science learning that utilize more in technology is called virtual lab. It helps the students to experiment more easily and also cheaper. Virtual lab helps students understand more easily to a subject and becomes a solution for limited laboratory devices. Online classes with simulations present opportunities and challenges in terms of student involvement in scientific practice. Development in online learning is needed to ensure that students will get access to high-quality activities/knowledge.

One of the science learning alternatives offered from this case is the use of a virtual laboratory called the Physics Education Technology (PhET) simulation. These simulations belong to the University of Colorado and are suggested by Sokolowski and Rackley for science education. They were produced by the Physics Education Technology (PhET) project and have been presented as free online applications. Interactive simulations are identified as 'Easy Java Simulations (EJS)'. There are simulations on physics, chemistry, and biology fields. The main purpose of PhET simulations is to help students learn by questioning and to support making practice in learning (Fan et al., 2018). The considerations in the selection of PhET simulations are based on: (1) Learning objectives, (2) the characteristics of teaching materials or materials, (3) Student cognitive development, (4) the excess of PhET simulated media, and (5) the availability of tools and materials. Students of class V-VI elementary School are leveled as concrete operational level. The design using PhET simulated media is appropriate for those students' developmental characteristics. Learning using PhET simulations allows us to see and do something, immerse in learning, and experience the things we learn. It is expected to affect on improving learning outcomes. Students' critical thinking skills and learning independence in both classes improved after using e-handouts assisted by PhET (Ramadan et al., 2020).

PhET simulations are in line with the development of the Industrial Revolution 4.0 so that the students have good literation in technology and become proficient in using them. Students can also learn to directly explore through the PhET simulation. The simulation can create abstract physics animations. The interaction is done by pressing a button, sliding an object, or entering data. The result of the interaction will be 
immediately seen. This case is strengthened by the research of Tuysuz (2010) which concluded that the virtual lab application gave a positive effect on the students' achievements and attitudes when compared to traditional teaching methods. Widowati et al (2017) states that students' thinking skills have progressed from one meeting to the next by using a virtual lab. The results of the study are in line with Ramadhan \& Irwanto (2017) who state that virtual labs can improve problem-solving ability, critical thinking, creativity, student conceptual understanding, science process skills, lab skills, motivation, interests, perception, and learning outcomes. Learning with PhET simulation is projected to improve the concepts of students' understanding and improve interpersonal competence by discussion together.

PhET simulation is expected to improve the effectiveness and efficiency of the learning process so the teachers only act as facilitators while the students become the subjects who actively look for information. The virtual laboratory uses computerized models, simulations, and various other instructional technologies to replace traditional lab activities. It provides many advantages. It is done in cyberspace so experimentation does not harm yourself or others. The affordable simulation costs, once developed, the tool can be used repeatedly at no additional cost. The virtual lab allows students to work independently or collaboratively regardless of the school laboratories, chemicals, and equipment available (Herga et al., 2016).

An appropriate learning approach will be able to achieve optimal results so the learning objectives can be achieved. To achieve learning success, teachers need to pay attention to the student learning patterns, master subject matter, choose the proper learning approach, and create the most effective learning situation. According to Hosnan (2014), the characteristics of learning with the scientific approach include student-centered learning. It involves skills in processing science in developing concepts, rules or principles, and involving potential cognitive processes in stimulating the development of intellect. Here is especially students with a high level of thinking skills so it can develop their character. Learning with a scientific approach is designed in such a way so the students can actively build concepts and rules or principles through observing and formulating problems, formulate hypotheses, collect and analyze data, and draw conclusions and communicating concepts. A scientific approach provides a logic of understanding the material used. Information may come from anywhere and anytime. It does not depend on the course of the teacher. Learning conditions through scientific approaches are expected to encourage students to observe. The application of scientific approaches in learning involves processing skills such as observing, classifying, measuring, predicting, explaining, and concluding. This research aims to develop online science teaching instruments based on scientific approaches using the appropriate PhET simulation to improve the learning outcomes of elementary school students.

Based on the research objectives, the researchers describe several research objectives more specifically. They are:

- Producing an online science learning tool based on scientific approaches using PhET simulation.

- Describing the validity of a scientific approach based online science teaching instruments using the improved PhET simulation: (a) Testing the conceptual validity of the developed Teaching instruments; (b) Testing the readability of the developed Teaching instruments; (c) Testing the difficulty level of the developed Teaching instruments. 
- Describing the practicality of online science teaching instruments based on scientific approaches using developed PhET simulation: (a) The implementation of online science learning activities based on scientific approaches using the PhET simulation media on material of electric; (b) The observed student activities during the learning process; (c) The found obstacles during the learning activities.

- Describing the effectiveness of online science teaching instruments based on scientific approaches using developed PhET simulation: (a) The increase in learning outcomes after implementation of online science Teaching instruments based on scientific approaches using the PhET simulation media on electrical material; (b) Students response to online science learning activities based on scientific approaches using PhET simulation.

\section{RESEARCH METHOD General Background}

This research uses a developmental method. The teaching instruments are developed, such as the lesson plan, student activity sheet, learning materials, and the assessment sheet of learning outcomes on material of electrical circuit. The development of the device is guided by the Model 4-D. The developmental research conducts in several phases, namely defining, designing, developing, and disseminating. The implementation of Teaching instruments uses the One Group Pre-Test-One Group PostTest design because it uses only one group without comparison. A group has been given a treatment using a scientific approach assisted by the PhET simulated media, then assessed to determine the level of achievement of a predefined indicator. Design research presented in Figure 1.

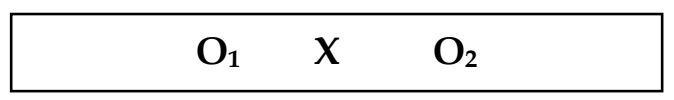

Figure 1. Research design.

\section{Sample / Participants / Group}

This research was conducted at State Elementary School Jagir I I/393 Surabaya in the even semester in the academic year 2019/2020. with three meetings plus pre-test and post-test. The research subject is a scientific approach-based teaching instrument using PhET simulations. The test subjects were students of the VA class as much as 20 people and VB class of 20 people at State Elementary School Jagir I I/393 Surabaya. The study was conducted in the even semester in the academic year 2019/2020. The researchers acted as the teachers.

\section{Instrument and Procedures}

The Data of the learning process, the student activity, and the obstacles during the learning are obtained through observations by two observers. Those data are noted using the observation sheets and rubric. Learning Data is obtained through an instrument test to measure and record students' learning outcomes on the material of electrical. The instruments are in the form of 30 questions multiple-choice tests with four options of answers each question. The test is performed twice, namely pre-test and post-test. The student response Data uses a poll that collects information about response to readability and difficulty level in understanding learning materials and student activity sheets, the use of PhET simulations in learning, the teacher explanation during learning activities, the teacher guidance when working on student activity sheets during 
activities, as well as problem/sheet of assessment of learning outcomes used. The student response poll is given after the entire learning process is completed.

\section{Data Analysis}

Teaching instruments are worthy of the research when fulfilling elements: valid, practical, effective. The validity is determined by the scale of the passing grade which is the average score $(\bar{X})$ of the calculation results by several validators then the validity level is determined by matching the criteria.

Table 1. Device category.

\begin{tabular}{ccc}
\hline Score Interval & Valuation Category & Description \\
\hline $3,6 \leq \mathrm{P} \leq 4$ & Very valid & Can be used without revision \\
$2,6 \leq \mathrm{P} \leq 3,5$ & Valid & Can be used with a slight revision \\
$1,6 \leq \mathrm{P} \leq 2,5$ & less valid & Can be used with many revisions \\
$1 \leq \mathrm{P} \leq 1,5$ & invalid & Not usable yet and still require revision \\
\hline
\end{tabular}

The instruments reliability is determined by the calculation of two observers with the degree of reliability is calculated by using formula (Borich, 2007):

Description:

$$
\text { Percentage of Agreement }=\left[1-\frac{A-B}{B+A}\right] \times 100 \%
$$

A: Frequency of the aspect assessed by the validator/observer by providing high frequencies; B: Frequency of the aspect assessed by the validator/observer by providing low frequencies. The Student activity observation instrument is reliable if the reliability value $R \geq 75 \%$ (Borich, 2007)

The analytical techniques for readability and student activity sheet are done in a qualitative descriptive based on the following readability. The percentage of learning material readability and student's activity sheet can be calculated using the formula:

$$
\text { Persentase }=\frac{\text { Number of } \text { students answered yes/agree }}{\text { Sum of all students }} \times 100 \%
$$

The percentages earned are then interpreted according to Table 2.

Table 2. Readability value of the device.

\begin{tabular}{cc}
\hline Percentage & Category \\
\hline$>60 \%$ & Low \\
$40-60 \%$ & Moderate \\
$<40 \%$ & Height \\
\hline
\end{tabular}

The level of difficulty analysis of learning materials and student's activity sheet is completed in a qualitative descriptive based on the following difficulty level. The percentage of difficulty level of learning materials and student's activity sheet can be calculated using the formula:

$$
\text { percentage }=\frac{\text { Number of } \text { students answered yes/agree }}{\text { Sum of all students }} \times 100 \%
$$


The percentage earned is interpreted according to Table 3

Table 3. Device difficulty value.

\begin{tabular}{cc}
\hline Percentage & Category \\
$>81 \%$ & Very hard to understand \\
$61 \%-80 \%$ & Hard to understand \\
$41 \%-60 \%$ & Less hard to understand \\
$21 \%-40 \%$ & Easy to understand \\
$<21 \%$ & Very easy to Understand \\
\hline
\end{tabular}

The results of learning are analyzed by calculating the observation results (perceived by observation) based on the average value of each section in the lesson plan and conventions using the criteria in Table 4.

Table 4. Criteria for learning implementation.

\begin{tabular}{cc}
\hline Average score Interval & Category \\
\hline$>3,6$ & Excellent \\
$2,8-3,6$ & Good \\
$1,902,7$ & Fair \\
$1,0-1,8$ & Bad \\
\hline
\end{tabular}

Percentage of students ' activity is calculated using the following formula:

$$
\mathrm{P}=\left(\frac{\Sigma_{\mathrm{K}}}{\Sigma_{\mathrm{N}}}\right) \times 100 \%
$$

Description:

P: The percentage of the student activity; $\Sigma K$ : The number of frequencies each appearing activity; $\Sigma \mathrm{N}$ : The number of all activity frequencies.

The obstacles in the teaching implementation are analyzed in descriptive qualitative, the data are obtained based on the notes by the observers. The researchers then provide solutions to overcome them. The percentage of responses is obtained then interpreted according to Table 5.

Table 5. Student response category.

\begin{tabular}{cc}
\hline Percentage & Category \\
\hline $81 \%-100 \%$ & Very good \\
$61 \%-80 \%$ & Good \\
$41 \%-60 \%$ & Fair \\
$21 \%-40 \%$ & Bad \\
$0 \%-20 \%$ & Very bad \\
\hline
\end{tabular}

In this study, the data processing of pre-test and post-test results uses the SPSS V16 program. From the pre-test and post-test results, the data then analyzed in a descriptive quantitative processing. The accomplishment of the indicator is calculated using the formula:

$$
\text { The accomplishment of the indicator }=\frac{\sum \text { Students who reach the indicator }}{\Sigma \text { Students }} \times 100 \%
$$

An indicator is said to be accomplished if $\geq 70 \%$ of students reach the indicator. The students are individually is said to be accomplished when the average achievement of 
indicators that represents the learning objective meets the minimum accomplishment criteria of State Elementary School Jagir I that set at 75. Student knowledge learning outcomes are analyzed by using the following formula.

$$
\text { Value }=\frac{\text { Score earned }}{\text { Maximum Score }} \times 100
$$

The classification of learning results in a classical formula is calculated:

$$
\text { Classical accomplishment }=\frac{\sum \text { Individual learners }}{\Sigma \text { students }} \times 100 \%
$$

The learning result is said to achieve the classical accomplishment if it meets the criteria of accomplishment of $\geq 85 \%$ (Anwar, 2016). The pre-test and post-test scores gained by students also demonstrate the effectiveness of the learning performed. To determine the improvement factor (gain), the researchers analyzed using the Hake formula as follows.

$$
g=\frac{S_{\text {post }}-S_{\text {pre }}}{S_{\text {max }}-S_{\text {pre }}}
$$

$g$ is the improvement in learning outcomes, $S_{\text {post }}$ is the average score in the post-test, $S_{\text {pre }}$ is the average score in the pre-test, and $S_{\max }$ is the maximum score. Hake classifies gain into $g$-high $(g \geq 0.7)$, g-medium $(0.7>\mathrm{g} \geq 0.3)$, and $g$-low $(g<0.3)$. Testing prerequisite analysis: (1) Conducting normality tests using Kolmogorov-Smirnov test statistics with a level of a significance $=0.05$; (2) Conducting homogeneity test with Levene test with the equivalent of a-significance $=0.05$. Hypothesis testing with an Independent T-Test with a significance of 0.05 is used to determine if there is a difference in learning outcomes for each class of one variable (N-Gain). The hypotheses tested in the Independent T-test include: $\mathrm{H}_{0}=$ There is no significant difference between the average $\mathrm{N}$-Gain between classes; $\mathrm{H}_{1}=$ There is a significant difference between the average N-Gain between classes. Basic decision Making: If the value of Sig. (2-Tailed) > 0.05 , then $\mathrm{H}_{0}$ accepted and $\mathrm{H}_{\mathrm{a}}$ rejected; If Sig. (2-Tailed) $<0.05$, then $\mathrm{H}_{0}$ rejected and $\mathrm{H}_{\mathrm{a}}$ accepted. The data analysis technique of affective learning outcomes by applying scientific approach based learning is calculated by the following formula:

$$
\text { Affective Learning score }=\frac{\sum \text { Acquisition Score }}{\sum \text { Maximum Score }} \times 100
$$

The description in the affective assessment development can be seen in Table 6.

Table 6. Affective learning results category.

\begin{tabular}{cc}
\hline Value & Category \\
\hline $0-20$ & Very bad \\
$21-40$ & Bad \\
$41-60$ & Fair \\
$61-80$ & Good \\
$81-100$ & Excellent \\
\hline
\end{tabular}

The students are said to be accomplished when obtaining affective learning outcomes with minimum submission criteria value of 75 . The data analysis of psychomotor learning outcomes are gained by applying teaching based on the scientific approaches then calculated with the following formula:

$$
\text { Psychomotor learning score }=\frac{\sum \text { Acquisition Score }}{\sum \text { Maximum Score }} \times 100
$$


Table 7. Category of psychomotor study results.

\begin{tabular}{cc}
\hline Value & Category \\
\hline $0-20$ & Very bad \\
$21-40$ & Bad \\
$41-60$ & Fair \\
$61-80$ & Good \\
$81-100$ & Excellent \\
\hline
\end{tabular}

The students are said to be accomplished when obtaining psychomotor learning outcomes with minimum submission criteria value of 75 .

\section{RESULTS AND DISCUSSION}

The teaching instrument are said to be appropriate in this research when fulfilling these elements: valid, practical and effective. The validity of the teaching instruments can be seen from the conceptual validity, readability of the device, and the difficulty of the device. The practicality of the learning tools can be seen from the implementation of teaching instruments and the obstacles that come then the students can solve. The effectiveness of the teaching instruments that used by students can be seen from the activities of students in the process of learning. It comes from the students' responses during and after learning performed and the improvement of student outcomes after learning.

Teaching instruments are considered as valid if they meet the criteria: 1) The conceptual validity of teaching instruments is appropriate if shown between $2.6 \leq \mathrm{SV} \leq$ 3.5 ; 2) The legibility rate of the student's handbook and students activity sheet is appropriate if shown between $40 \%$ to $60 \%$; and 3) The difficulty level of student teaching book and students activity sheet maximum should be $40 \%$ with categorized as easy to understand. The data validation results are analyzed in descriptive qualitative. The validity is determined by the passing grade with the average score $(\bar{x})$ of the assessment results of the device by the validators. It determined the validity level of the device developed by matching the criteria.

Table 8. Validation results.

\begin{tabular}{|c|c|c|c|c|}
\hline Validity & Device & $\begin{array}{c}\text { Average } \\
\text { Rating }\end{array}$ & $\begin{array}{l}\text { Percentage of } \\
\text { Agreement }\end{array}$ & Description \\
\hline \multirow{5}{*}{$\begin{array}{l}\text { Conceptual } \\
\text { validity }\end{array}$} & Syllabus & 3,46 & $94,05 \%$ & Very Valid \\
\hline & Lesson plan & 3,44 & $95,80 \%$ & Very Valid \\
\hline & Evaluation sheet & 3,35 & $93,88 \%$ & Very Valid \\
\hline & Student activity sheets & 3,44 & $94,12 \%$ & Very Valid \\
\hline & $\begin{array}{l}\text { Student learning } \\
\text { materials }\end{array}$ & 3,35 & $93,88 \%$ & Very Valid \\
\hline \multirow[t]{2}{*}{ Readability level } & $\begin{array}{l}\text { Student learning } \\
\text { materials }\end{array}$ & $88 \%$ & & High \\
\hline & Student activity sheets & $90 \%$ & & High \\
\hline \multirow[t]{2}{*}{ Difficulty level } & $\begin{array}{l}\text { Student learning } \\
\text { materials }\end{array}$ & $32,5 \%$ & & $\begin{array}{l}\text { Easy to } \\
\text { understand }\end{array}$ \\
\hline & Student activity sheets & $33,9 \%$ & & $\begin{array}{c}\text { Easy to } \\
\text { understand }\end{array}$ \\
\hline
\end{tabular}

The selected learning activity is a website-based online learning model. The websitebased learning Model is designed by integrating learning with websites into conventional face-to-face learning programs (Prastowo, 2013). Conventional in-face 
learning processes are virtually full-fledged while providing the opportunity to interact with one another to communicate directly and face-to-face if needed through an Internet application. The teacher uses laptops, internet, and mobile phones as a learning tool, while students simply use their parents' mobile phones to access learning materials and learning activities. The e-learning model uses WhatsApp group media to coordinate the students and give explanations and share tasks or links, Google form for work on the pre-test and post-test, and scoring. The virtual learning is assisted by Google meet and Hangout meet to perform online learning and face-to-face with students in the implementation of learning activities following the lesson plan that has been assigned the syntax. For material enrichment, the teacher uses learning videos that uploaded on YouTube so the students can re-watch and understand the learning activities repeatedly.

The practicality of teaching instruments is reviewed the process of learning through the practice of learning, the student activity, and the obstacles during implementation. A learning tool is said to be practical if 1 ) the performance of learning earns an average of a minimum observation score of 3.00 with a good category; 2) The percentage results of the observed student activity at least $66 \%$ in the good category; 3 ) the obstacles found during learning activities can be overcome. The aspect organized in RPP was 100\% carried out for 3 meetings. The average implementation rate of the lesson plan reach 3.30 - 3.47 with a percentage of agreement 90.5 - 93.6. The aspect organized in the lesson plan reaches $100 \%$ carried out for 3 meetings. The average implementation rating in the lesson plan reach $3.30-3.47$ with a percentage of agreement 90.5 - 93.6.

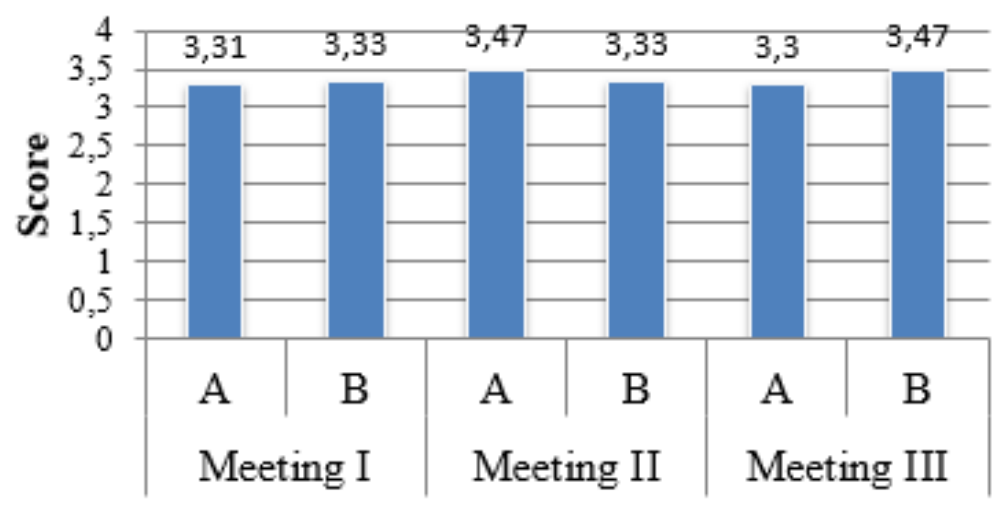

Figure 2. Average score for learning.

On average, most activities of the student in class $\mathrm{A}$ are reading and working on student activity sheets while the lowest activity is responding to friends' presentations. On average, the highest activity in class B is reading to observe and concluding the result while the lowest activity is responding to friends' presentations. Activities in responding to the friends' presentations are noted in the learning process because the students cannot actively give questions or respond when their friends make presentations. Student activity observations are described in Figure 3. 


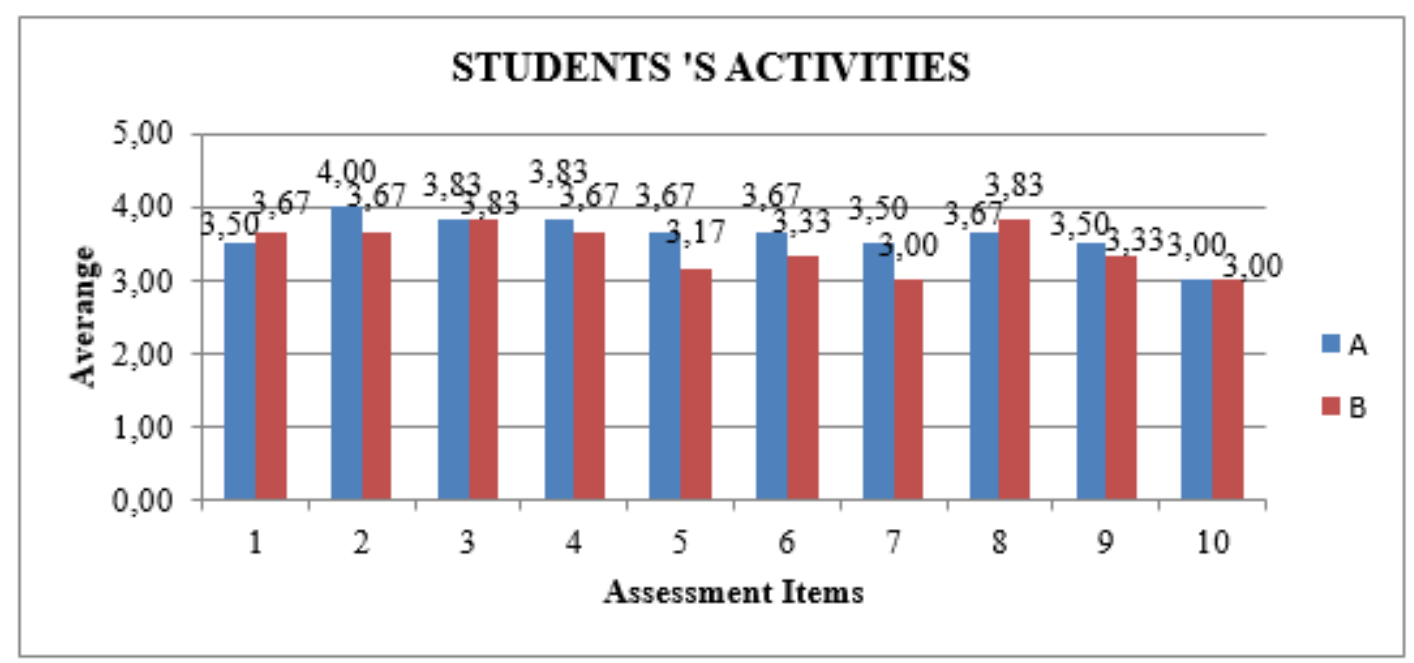

Figure 3. The average score of students' activities.

Description of the evaluation aspect: 1. Attention to teacher explanation, 2. Read learning materials and work on the student activity sheets, 3 . Observe, 4 . Convey the question, 5. Experimenting with PhET simulation, 6. Analyzing the data from the experiment results, 7. Presenting the results of the experiment, 8. Conclude the results of the experiment, 9. Communicating the experiment results, 10 Respond to friend presentations. The obstacles that occurred during the learning activities are noted by two observers. The obstacles samples such as the students that are not friends yet to use the PhET simulation or define the variables in the experiment. Both observers use an observation sheet of the obstacles in the learning process in Table 9.

Table 9. The implementation of overcoming obstacles.

\begin{tabular}{cll}
\hline No & \multicolumn{1}{c}{ Obstacles } & \multicolumn{1}{c}{ Input/Solution } \\
\hline 1 & $\begin{array}{l}\text { The students are not friendly to learn online } \\
\text { so that it needs more preparation and more } \\
\text { internet quota. }\end{array}$ & $\begin{array}{l}\text { The teachers guide and explain directly } \\
\text { about the guidance of the work. }\end{array}$ \\
2 & $\begin{array}{l}\text { The students have difficulty during } \\
\text { experiments while creating electrical circuits } \\
\text { using PhET simulations on mobile phones } \\
\text { due to the too-small screen size. }\end{array}$ & $\begin{array}{l}\text { The teachers guide students to be more } \\
\text { thorough and the continue tries so that } \\
\text { they will get used to using mobile } \\
\text { phones. }\end{array}$ \\
& $\begin{array}{l}\text { The students still struggle too hard to analyze } \\
\text { the results of the experiment and conclude } \\
\text { that it needs more mentoring. }\end{array}$ & $\begin{array}{l}\text { The teachers more precisely guide and } \\
\text { explain so the students are more } \\
\text { familiar with how to analyze and } \\
\text { conclude experiment results. }\end{array}$ \\
& $\begin{array}{l}\text { The student's preparation for the } \\
\text { presentation is less than enough. This is } \\
\text { showed when asked by one of the students is } \\
\text { still showing each other. }\end{array}$ & $\begin{array}{l}\text { The teacher motivates and gives a } \\
\text { resupply before presenting. }\end{array}$ \\
\end{tabular}

Based on Table 9, it can be explained that the constraints experienced by students occurred during the experiment using PhET simulation. The result of limited trial shows the index of item sensitivity between $0.3-0.60$. It shows that all items $(100 \%)$ are in the sensitive categories. It shows that the learning outcomes are influenced by the learning process. The effectiveness of the teaching instrument includes 1) Teaching instruments are said as effective if the average percentage of students' response is at 
least $61 \%$ with good criteria; 2 ) the students learning results are said to improve if the value of $\mathrm{N}$-gain $>0.3$ with a medium category. Based on analysis of the level of achievement of indicators, class A has $2(6.67 \%)$ indicators that are not reached and 28 $(93.33 \%)$ indicators is successfully achieved, while in class B there are $5(16.67 \%)$ indicators that are not achieved and $25(83.33 \%)$ indicators are achieved. The overall indicator level of achievement is $4(13.33 \%)$ unreached indicators and $26(86.67 \%)$ successful. class A has a higher achievement of successful indicators than class B.

The pre-test result of class A ranges from 23 - 50 with the average pre-test rate of 38, while class B ranges from $23-47$ with an average rate of 38 . The post-test score of class A ranges from 67 - 97 to the average post-test rate of 85, while class B ranges from 67 97 to the average post-test score of 82 . Based on the post-test score, the accomplishment in class A shows that $3(15 \%)$ students do not complete while the other $17(85 \%)$ complete. Class B post-test ranges from 70 - 97 with $5(25 \%)$ students do not complete and $15(75 \%)$ complete. Based on the results it can be said that the indicator is accomplished in classical.

Table 10. N-Gain value.

\begin{tabular}{|c|c|c|c|c|c|c|c|c|c|}
\hline \multirow{2}{*}{ Initial } & \multicolumn{4}{|c|}{ Class A } & \multirow{2}{*}{ Initial } & \multicolumn{4}{|c|}{ Class B } \\
\hline & Pre-test & Post-test & N-Gain & Category & & Pre-test & Post-test & N-Gain & Category \\
\hline A1 & 33 & 90 & 0.85 & High & B1 & 47 & 70 & 0.44 & Medium \\
\hline A2 & 37 & 87 & 0.79 & High & B2 & 47 & 90 & 0.81 & High \\
\hline A3 & 43 & 93 & 0.88 & High & B3 & 27 & 67 & 0.55 & Medium \\
\hline A4 & 30 & 83 & 0.76 & High & B4 & 47 & 73 & 0.50 & Medium \\
\hline A5 & 50 & 93 & 0.87 & High & B5 & 40 & 93 & 0.89 & High \\
\hline A6 & 43 & 67 & 0.41 & Medium & B6 & 33 & 77 & 0.66 & Medium \\
\hline A7 & 40 & 80 & 0.67 & Medium & B7 & 43 & 90 & 0.82 & High \\
\hline A8 & 50 & 93 & 0.87 & High & B8 & 43 & 97 & 0.94 & High \\
\hline A9 & 23 & 67 & 0.57 & Medium & B9 & 23 & 80 & 0.74 & High \\
\hline A10 & 23 & 90 & 0.87 & High & B10 & 47 & 83 & 0.69 & Medium \\
\hline A11 & 27 & 90 & 0.86 & High & B11 & 53 & 80 & 0.57 & Medium \\
\hline A12 & 27 & 80 & 0.73 & High & B12 & 33 & 90 & 0.85 & High \\
\hline A13 & 33 & 73 & 0.60 & Medium & B13 & 30 & 80 & 0.71 & High \\
\hline A14 & 50 & 80 & 0.60 & Medium & B14 & 27 & 77 & 0.68 & Medium \\
\hline A15 & 47 & 83 & 0.69 & Medium & B15 & 27 & 73 & 0.64 & Medium \\
\hline A16 & 33 & 87 & 0.80 & High & B16 & 33 & 97 & 0.95 & High \\
\hline A17 & 40 & 87 & 0.78 & High & B17 & 40 & 80 & 0.67 & Medium \\
\hline A18 & 37 & 97 & 0.95 & High & B18 & 43 & 83 & 0.71 & High \\
\hline A19 & 50 & 97 & 0.93 & High & B19 & 37 & 80 & 0.68 & Medium \\
\hline A20 & 47 & 90 & 0.81 & High & B20 & 40 & 73 & 0.56 & Medium \\
\hline Average & 38 & 85 & 0.76 & High & & 38 & 82 & 0.70 & High \\
\hline
\end{tabular}

Based on Table 10. N-Gain value in class A ranges from $0.46-0.95$ with $30 \%$ of students in medium criteria and $70 \%$ in high criteria. The average value of the N-Gain of Class A is 0.76 with high criteria. The N-Gain value of class B ranges from $0.44-0.95$ with rate of $55 \%$ of students on moderate criteria and $45 \%$ on high criteria. The average $\mathrm{N}-$ Gain of class B values of 0.70 with high criteria. After obtaining the pre-test and posttest scores, the researchers conduct analysis of the value gained. The analysis used is $\mathrm{N}$ Gain test. This test is used to determine the effectiveness of the given learning. N-Gain test results showed the average $\mathrm{N}$-gain in class $\mathrm{A}$ is 0.76 with high criteria and an average N-Gain class B is 0.70 with high criteria. The results show that learning with scientific approaches with PhET media is able to improve student learning outcomes. 
Teaching media develop as the advancement of science and technology. One of the media as a result of the technology is PhET simulation. PhET allows students to connect real-life phenomena and the underlying science, making those that don't appear to be visible. Besides, PhET provides direct feedback in the moment of changes made by students or teachers while using the media. It allows students to investigate causal relationships and scientific questions through a deeper simulation exploration. Therefore, the use of the PhET simulation media is expected to improve the students' conceptual understanding. besides, the integration of virtual simulations in learning will optimize students' scientific creativity (Astutik \& Binar, 2018).

The results above show the real role of virtual simulation media in increasing the effectiveness of the use of learning approaches with interactive media. Virtual simulation Media in learning can be used as a means of sharpening the explanation of the direct learning activities, demonstrate a phenomenon using props, or replace the role of the props especially that is not possible to do before the real class. The use of a virtual laboratory has a better effect than the interactive demonstrations using real lab equipment regarding the conceptual understanding of the direct current electric circuit (Faour \& Ayaobi, 2018).

It is in line with the research of Prihatiningtyas et al (2013) who states that learning results using PhET simulations is more effective than a simple teaching instrument. The teaching materials using simulated media can improve student learning outcomes when compared to using learning regular textual teaching materials. Some of those studies have shown that the use of simulated media is capable of improving students' learning outcomes. The obtained N-Gain value is used to perform the hypothesis analysis. Based on the prerequisite test results in the form of test normality and homogeneity test, the data meet the prerequisite test. Based on the results of the test of output normality using the Kolmogorov-Smirnov test, the result gives Asymp value. Sig. (2-tailed) in-class is A 0.797 and class B is 0.927 . the test of normality shows that all data are distributed normally.

Table 11. Test normality.

\begin{tabular}{lll}
\hline & Class A & Class B \\
\hline $\mathrm{N}$ & 20 & 20 \\
Kolmogorov-Smirnov Z & .647 & .546 \\
Asymp. Sig. (2-tailed) & .797 & .927 \\
\hline
\end{tabular}

a. Test distribution is Normal.

Based on the results of the output of the homogeneity test using the Levene technique, the Sig value shows 0.866 . These results show the data are homogeneous.

Table 12. Test homogeneity.

\begin{tabular}{llll}
\hline N-Gain & & & \\
\hline Levene Statistic & df1 & df2 & Sig. \\
\hline .029 & 1 & 36 & .866 \\
\hline
\end{tabular}

The prerequisite test for data analysis has been fully completed so the data can be tested with a test T-independent test. The results of the statistical test output of the 
Independent T-test showed a value of T is 1.305 with a value of Sig. (2-Tailed) is 0.200. These results indicate there is no significant difference between class A and class $\mathrm{B}$.

Table 13. Independent T-Test.

\begin{tabular}{|c|c|c|c|c|c|c|c|c|c|}
\hline & & \multicolumn{4}{|c|}{$\begin{array}{l}\text { Levene's Test } \\
\text { for Equality of } \\
\text { Variances }\end{array}$} & \multicolumn{4}{|c|}{ T-test for Equality of Means } \\
\hline & & \multirow[t]{2}{*}{$\mathbf{F}$} & \multirow[t]{2}{*}{ Sig. } & \multirow[t]{2}{*}{$\mathbf{T}$} & \multirow[t]{2}{*}{ Df } & \multirow[t]{2}{*}{$\begin{array}{l}\text { Sig. (2- } \\
\text { tailed) }\end{array}$} & \multirow[t]{2}{*}{$\begin{array}{l}\text { Mean } \\
\text { Difference }\end{array}$} & \multirow[t]{2}{*}{$\begin{array}{l}\text { Std. Error } \\
\text { Difference }\end{array}$} & $\begin{array}{l}95 \% \\
\text { Confidence } \\
\text { Interval of the } \\
\text { Difference }\end{array}$ \\
\hline & & & & & & & & & Lower Upper \\
\hline \multirow[t]{2}{*}{ N-Gain } & $\begin{array}{l}\text { Equal } \\
\text { variances } \\
\text { assumed }\end{array}$ & .029 & .866 & 1.305 & 36 & .200 & .06105 & .04679 & -.03385. 15596 \\
\hline & $\begin{array}{l}\text { Equal } \\
\text { variances not } \\
\text { assumed }\end{array}$ & & & 1.305 & 35.949 & .200 & .06105 & .04679 & -.03386. 15596 \\
\hline
\end{tabular}

Table 13 shows that the learning process in both classes that given the same treatment shows no different results. These results show that teaching instruments developed and applied to both classes are appropriate for use for broader trials because it can give equal/consistent results. In the students' learning results in the domain of psychomotor, the average value of class $\mathrm{A}$ is 80.12 with the details of $90 \%$ (18 persons) complete and 10\% (2 people) do not complete. The average value of class B is 77.08 with the details of $85 \%$ (17 persons) complete and 15\% (3 persons) do not complete. The result of the overall psychomotor of students is $87.5 \%$ (35 people) complete and $12.5 \%$ (5 persons) do not complete. It is in line with the achievement of Hernawati, et al. (2018) who state scientific approaches have an appropriate learning syntax to enhance and develop students' academic skills and give them a variety of skills. Triyuni (2016) stated that the scientific approach provides a positive and good learning environment that is conducive to improve the students' skills. Therefore, the exploration through learning activities in observation, making questions related to observation, conducting experiments, reasoning, and communicating results through various interpretations are still needed to improve.

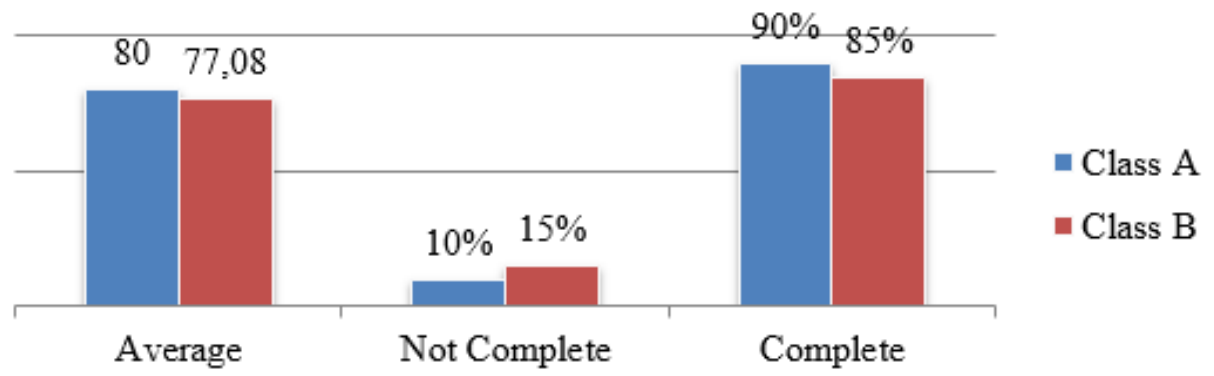

Figure 4. The learning results of psychomotor domains.

Based on Figure 4 below, the student learning outcomes in the affective domain gain class A 80.00 and in class B 80.31 in the average value. Both classes accomplished amounted to $100 \%$ in affective domains. According to Cahyani et al. (2014), multimediaassisted learning can improve the attitude of curiosity, cooperation, creativity, and 
environmental awareness. The learning situation used at the moment is an online learning situation. The online learning is well organized according to the achieved indicators. The learning process is completed according to the schedule prepared by the teacher. The students attend online classes at the scheduled time.

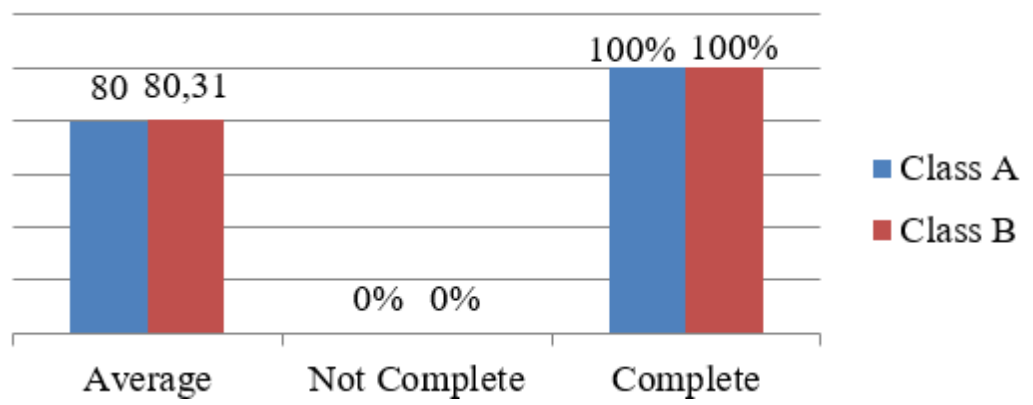

Figure 5. The learning results in affective domains.

The learning process of a scientific approach based using PhET simulations makes the students interested to pay attention to the lessons or other materials. A response poll is given to all students who join the learning in Class A and Class B. the average percentage of students' response rate is $88 \%$. The percentage of students' responses to the teacher's in describing learning material is $85 \%$. The response of the students in scientific activities tend to be high. It can be seen from the average of $88 \%$ who say comforted in how the teachers give guidance while observing, $90 \%$ say comforted in how the teachers give guidance while questioning, 93\% say comforted in how teachers give guidance when experimenting, $85 \%$ comforted to how teachers give guidance when associating, and $83 \%$ comforted in how teachers give guidance when communicating. Overall, the students give positive responses to the learning process. It can motivate the students to boost their attention and get them involved in a fun and meaningful learning experience. This motivation encourages the students to perform learning activities as perceived by the observers. The high response rate of the students can indirectly help themselves to achieve high learning outcomes. From the response conclusion, the students are generally attracted to scientific approach based learning components using PhET simulations. They agree that further learning should be given in the same way. They also state that learning based on scientific approaches using PhET simulations is interesting and makes it easier to receive lessons. Developing learning science subject emphasizes the discovery of concepts through scientific approaches so the students have experience with the objects they learn. The experience can be gained by students through online learning with PhET media. Students can dabble their experiments virtually. Learning with the virtual media is in line with the theory of experience that Edgar Dale has discovered. His theory gives the idea that student learning experiences can be done through the process of doing or experiencing where the learning way has higher accuracy because the outcome tends to be concrete (Sanjaya, 2010). Learning with PhET simulations has the benefit of being able to make the invisible appear and provide multiple representations (macroscopic, microscopic, graphics, etc.) of abstract concepts (Ceberiol et al., 2016).

Learning is aimed to find out and to do an action to make the students to gain understanding and build on it still by tutored by the teacher. Learning goes as the process of finding a concept that built-in mind to make the learning meaningful. Yulianti et al (2018) stated after inquiry-based learning with PhET simulations were introduced, some changes occurred to the problem-solving strategies used by some 
students to become more scientific, structured, and memory-based. The meaningful learning outcomes are expected to have a high retention power as students understand more deeply.

That way is coherent with the Wieman, et al (2008) who explain that PhET simulation works better when combined with activities that allow students to work directly with programs to build their conceptual understanding of science through exploration. This kind of activity can be done with small study groups in lab or recitation or as a homework assignment. Learning science requires the students to observe objects and events, ask questions, acquire knowledge, develop explanations of natural symptoms, test the explanation in different ways, and communicate the idea to another group. Learning science in observing objects are generally done in science laboratories. However, not all schools have laboratories. Therefore, the solution is using a virtual laboratory where the students can experiment virtually and get the necessary data. One of the virtual labs is through the PhET application, which contains physical, chemical, biological, and mathematical materials. The use of the PhET application is expected to improve better results of science learning if compared to conventional classes. Based on Edgar Dale's theory of expressing knowledge, it can be absorbed by $90 \%$ when presented through real experimentation or simulated. Online learning should be able to provide a variety of learning activities to accommodate different learning styles. The students will choose the most appropriate strategy to obtain their learning needs.

Various pre-learning activities can be used in preparing students about the lesson and to keep them connected and motivated to learn by online. Before it is conducted, the students should be shown about the lesson target so they knew when and how to achieved the outcome of the lesson. The students must be notified of learning requirements so they can check if they are ready for the lesson. Necessary instructions should be given beforehand so that students will use interactive simulations in line with their purpose. To benefit from interactive simulations at the highest level, results should be discussed in groups, and individual presentations should be ensured (Araci \& Yilmas, 2020).

\section{CONCLUSIONS}

Teaching instruments that developed (lesson plan, student activity sheets, student learning materials, and assessment sheet of learning outcomes) in this study successfully fulfill the criteria for validity, practicality, and effectiveness. The validity of teaching instruments includes conceptual validity, readability, and the difficulty levels. The practicality of teaching instruments includes the implementation of learning, the student activity, and the obstacle during learning activities. Learning effectiveness involves the improvement of learning outcomes and the student responses to learning activities. Based on the fulfillment of validity, criteria, and effectiveness criteria, the teaching instruments developed are appropriate to use in the learning process. The research implication is that a qualified online science learning based on a scientific approach using PhET simulations can be used to enhance the learning outcomes of elementary school students in science learning. Further research that can be done is to prove the quality of online science learning based on scientific approaches using PhET simulations in terms of practicality and effectiveness to increase learning outcomes in larger samples. 


\section{REFERENCES}

Amir, \& Haling, A. (2018). The effect of scientific approach at natural science learning on elementary students' learning outcome. Advances in Social Science, Education and Humanities Research (ASSEHR), 227, 13-15.

Anwar, S. (2016). Metode penelitian. Yogyakarta: Pustaka Pelajar.

Araci, F., \& Yilmas, R. M. (2020). The effect of laboratory experiment and interactive simulation use on academic achievement in teaching secondary school force and movement unit. Elementary Education Online, 19(2), 465-476.

Asrizal, A., Amran, A., Ananda, A., Festiyed, F., \& Sumarmin, R. (2018). The development of integrated science instructional materials to improve students' digital literacy in scientific approach. Jurnal Pendidikan IPA Indonesia, 7(4), 442-450.

Astutik, S., \& Binar, K. (2018). The practicality and effectiveness of collaborative creativity learning (CCL) model by using PhET simulation to increase students scientific creativity. International Journal of Instruction, 11(4), 409-424.

Borich, G.D. (2007). Effective teaching methods research based practice. New Jersey: Pearson Education.

Cahyani, R., Rustaman, N. Y., Arifin, M., \& Hendriani, Y. (2014). Kemampuan kognisi, kerja ilmiah dan sikap mahasiswa non IPA melalui pembelajaran inkuiri berbantuan multimedia. Jurnal Pendidikan IPA Indonesia, 3(1), 1-4.

Ceberiol, M., Almudi, J.S., \& Franco, A. (2016). Design and application of interactive simulations in problem solving in university-level physics education. Journal Science Education and Technology, 25(4), 590-609.

Citrasmi, N.W., Wirya, I.M., \& Tegeh, I.M. (2016). Pengaruh model pembelajaran scramble berbantuan media gambar terhadap hasil belajar IPA di SD. E-journal Undiksha, 4(1), 1-10.

Duda, H.J. (2010). Pembelajaran berbasis praktikum dan asesmennya pada konsep sistem ekskresi untuk meningkatkan kemampuan berpikir kritis siswa kelas XI. Jurnal VOX Edukasi, 1(2), 29-39.

Fan, X., Geelan, D., \& Gillies, R. (2018). Evaluating a novel instructional sequence for conceptual change in physics using interactive simulations. Education Sciences, 8(1), 29.

Faour, M.A, \& Ayoubi, Z. (2018). The effect of using virtual laboratory on grade 10 students' conceptual understanding and their attitudes towards physics. Journal of Education in Science, Environment and Health, 4(1), 54-68.

Herga, N.R., Čagran, B., \& Dinevski, D. (2016). Virtual laboratory in the role of dynamic visualisation for better understanding of chemistry in primary school. Eurasia Journal of Mathematics, Science \& Technology Education, 12, 593-608.

Hernawati, D., Amin, M., Irawati, M.H., \& Omar, N. (2018). The effectiveness of scientific approach using encyclopedia as learning materials in improving students' Science process skills in Science. Jurnal Pendidikan IPA Indonesia, 7(3), 266-272.

Hosnan, M. (2014). Pendekatan saintifik dan kontekstual dalam pembelajaran abad 21: kunci sukses implementasi kurikulum 2013. Jakarta. Ghalia Indonesia.

Kemdikbud. (2014). Permendikbud no. 103 tahun 2014 tentang pembelajaran pada pendidikan dasar dan pendidikan menengah. Jakarta: Kemdikbud.

Lazanyi, K.R. (2012). Study for nothing? literature overview of labour market opportunities of individuals with tertiary education. Budapest: Óbuda University.

Prastowo, A. (2013). Panduan kreatif membuat bahan ajar inovatif. Yogyakarta: Diva Press. 
Prihatiningtyas, S., Prastowo, T., \& Jatmiko, B. (2013). Implementasi simulasi PhET dan kit sederhana untuk mengajarkan keterampilan psikomotor peserta didik pada pokok bahasan alat optik. Jurnal Pendidikan IPA Indonesia, 2(1), 18-22.

Purwanto. (2011). Evaluasi hasil belajar. Yogyakarta, Pustaka Pelajar.

Ramadan, E.M., Jumadi, \& Astuti, D.P. (2020). Application of e-handout based on PhET simulation to improve critical thinking skills and learning independence of high school students. Journal of Physics: Conference Series, 1440, 1-7.

Ramadhan, M.F., \& Irwanto. (2017). Using virtual labs to enhance students' thinking abilities, skills, and scientific attitudes. International Conference on Educational Research and Innovation (ICERI 2017), 494-499.

Sanjaya, W. (2010). Strategi pembelajaran. Jakarta: Kencana Prenada Media Group

Susilana, R., \& Riyana, C. (2017). Media pembelajaran. Bandung: CV Wacana Prima.

Triyuni, T. (2016). The influence of science learning set using scientific approach and problem solving model on learning outcomes of junior high school students in the subject of heat and temperature. Jurnal Pendidikan IPA Indonesia, 5(2), 177-185.

Tuysuz, C. (2010). The effect of the virtual laboratory on student's acheivement and attitud in chemistry. International Journal of Educational Sciences, 2(1), 37-53.

Widowati, A., Nurohman, S., \& Setyowarno, D. (2017). Development of inquiry-based science virtual laboratory for improving student thinking skill of junior high school. Jurnal Pendidikan Matematika dan Sains, 4(2), 170-177.

Wieman, C.E., Adams, W.K. \& Perkins, K.K. (2008). PhET: Simulations that enhance learning. Science, 322, 682-683.

Yulianti, L., Riantoni, C., \& Mufti, N. (2018). Problem-solving skills on direct current electricity through inquiry-based learning with PhET simulations. International Journal of Instruction, 11(4), 123-138.

*Taufik Adi Sarwoto (Corresponding Author)

Postgraduate of Universitas Negeri Surabaya, Indonesia

Jl. Raya Kampus Unesa, Lidah Wetan, Kec. Lakarsantri, Kota SBY, Jawa Timur 60213 Indonesia

Email: taufik.18050@mhs.unesa.ac.id

Prof. Dr. Budi Jatmiko, M.Pd.

Postgraduate of Universitas Negeri Surabaya, Indonesia

Jl. Komplek Universitas Negeri Surabaya Gedung D1, Jl. Ketintang Sel. No.Kel, Ketintang, Kec.

Gayungan, Kota SBY, Jawa Timur 60231 Indonesia

Email: budijatmiko@unesa.ac.id

\section{Dr. Elok Sudibyo, M.Pd.}

Postgraduate of Universitas Negeri Surabaya, Indonesia

Jl. Komplek Universitas Negeri Surabaya Gedung D1, Jl. Ketintang Sel. No.Kel, Ketintang, Kec. Gayungan, Kota SBY, Jawa Timur 60231 Indonesia

Email: eloksudibyo@unesa.ac.id 